Katarzyna Wlaźlak*

\title{
Prawny model współpracy zagranicznej samorządu województwa
}

Szerzej pojmowana lokalna i regionalna współpraca zagraniczna miała początkowo charakter jedynie nieformalny. W zasadzie była to współpraca przygraniczna ograniczająca się do wymiany doświadczeń, wzajemnych wizyt, konsultacji i oświadczeń, zaś realizacja konkretnych zadań następowała na podstawie prawa cywilnego ${ }^{1}$. Pierwotnie możliwość tworzenia tzw. przygranicznych obszarów cennych przyrodniczo dopuszczała ustawa z dnia 16 października 1991 r. o ochronie przyrody ${ }^{2}$. Obszary te mogły być wyznaczane w drodze porozumienia z sąsiednimi państwami w celu ich wspólnej ochrony (art. 33 ust. 2). W 1993 r. w stosunku do Polski weszła w życie konwencja madrycka ${ }^{3}$ umożliwiająca już nie tylko zagraniczną współpracę o charakterze przygranicznym, ale i współpracę między jednostkami niemającymi wspólnej granicy, w tym międzyregionalną. Zawarte w konwencji kwestie dotyczące obowiązków państw w zakresie rozwiązywania problemów prawnych i administracyjnych we współpracy transgranicznej uzupełnia Europejska Karta Samorządu Lokalnego sporządzona w Strasburgu dnia 15 października 1985 r., przez Polskę ratyfikowana w 1994 r. ${ }^{4}$ Ponadto, deklaracją współpracy transgranicznej jest Europejska Karta Regionów Granicznych i Transgranicznych ${ }^{5}$, będąca jednak tylko aktem międzynarodowym soft law.

* Dr, Katedra Prawa Administracyjnego i Nauki Administracji Uniwersytetu Łódzkiego.

${ }^{1}$ R. Kusiak, Wspólpraca regionów i gmin o zasięgu przekraczajacym granice państwowe, „Samorząd Terytorialny” 1996, nr 7-8, s. 137.

2 Dz. U. nr 114, poz. 492 ze zm. (uchylona).

${ }^{3}$ Europejska Konwencja Ramowa o Współpracy Transgranicznej między Wspólnotami i Władzami Terytorialnymi, sporządzona w Madrycie dnia 21 maja 1980 r. (Dz. U. nr 61, poz. 287 i 288).

${ }^{4}$ Dz. U. z 1994 r., nr 124, poz. 607 ze sprost. i 608.

${ }_{5}^{5}$ Dokument międzynarodowy podpisany w 1981 r. przez Stowarzyszenie Europejskich Regionów Przygranicznych, w 1995 r. znowelizowany w Szczecinie, w Euroregionie Pomerania, od tego czasu określany także „Kartą Szczecińską” (wcześniej znany jako Europejska Karta Regionów Przygranicznych). 
W tamtym okresie na potrzebę zagranicznej współpracy regionalnej explicite zwracała uwagę także ustawa z dnia 8 sierpnia 1996 r. o zmianie ustawy o terenowych organach rządowej administracji ogólnej ${ }^{6}$, której art. 10 ust. 1 pkt 7 upoważniał wojewodów do podejmowania współpracy z właściwymi organami innych państw w zakresie współpracy transgranicznej i międzynarodowej współpracy międzyregionalnej na zasadach określonych przez ministra spraw zagranicznych. W związku z ustanowieniem samorządu województwa jako nowego podmiotu współpracy międzyregionalnej, wojewoda wprawdzie zachował w tym zakresie pewne kompetencje, niemniej obecnie wykonuje je w skali ogólnokrajowej, jako przedstawiciel Rady Ministrów w województwie. Zgodnie z aktualnym brzmieniem art. 23 ust. 1 pkt 2 ustawy z dnia 23 stycznia 2009 r. o wojewodzie i administracji rządowej w województwie ${ }^{7}$ do wojewody należy współdziałanie z właściwymi organami innych państw oraz międzynarodowych organizacji rządowych i pozarządowych, na zasadach określonych przez ministra właściwego do spraw zagranicznych.

Nowy podział kompetencji między administrację rządową i samorządową w województwie, który nastąpił w wyniku reformy administracji publicznej z 1998 r., wprowadził w praktyce pewien chaos w dotychczasowych stosunkach z partnerami zagranicznymi. Szczególnie było to widoczne na Ukrainie, gdzie nie istnieją porównywalne struktury administracyjne w obwodach. Przewodniczący obwodowych administracji państwowych, pełniący funkcję przedstawicieli tej władzy w terenie, początkowo - zamiast do województw samorządowych - kierowali propozycje nawiązania współpracy do wojewodów ${ }^{8}$. W obwodzie działa wprawdzie обласна рада reprezentująca samorząd, niemniej jest to władza niesamodzielna, o bardzo ograniczonych kompetencjach i budżecie na realizację przydzielonych zadań. Te ograniczenia dotyczą również rejonów będących odpowiednikami polskich powiatów. Bez - planowanej od ponad 10 lat - reformy ukraińskiego samorządu terytorialnego niewielka wydaje się też rola obu tych jednostek samorządowych we współpracy transgranicznej i międzyregionalnej ${ }^{9}$.

Dynamiczny rozwój lokalnej i regionalnej współpracy zagranicznej przypada na lata 90. XX i początek XXI w. Do najważniejszych tego przyczyn zalicza się wprowadzenie ustroju demokratycznego, ukształtowanie się nowych granic (na skutek rozpadu ZSRR, Czechosłowacji, Jugosławii), ustanowienie samorządności terytorialnej, proces integracji Polski z Unią Europejską oraz funkcjono-

${ }^{6}$ Dz. U. nr 106, poz. 498 (uchylona).

${ }^{7}$ Dz. U. nr 31, poz. 206 ze zm.

${ }^{8}$ K. Kaczmarczyk, Wybrane aspekty wspótpracy transgranicznej, „Samorząd Terytorialny” 2001, nr 7-8, s. 36.

${ }_{9}$ Współczesne problemy rozwoju tej współpracy między Polską a Ukrainą analizuje m.in. S. Korniievskyi, Role of the local government in the cross-border and interregional cooperation between Poland and Ukraine, „Administracja. Teoria - Dydaktyka - Praktyka” 2014, nr 2, s. 134-146. 
wanie programów wspierających współpracę (m.in. Interreg, Phare) ${ }^{10}$. W $1997 \mathrm{r}$. prawo przystępowania do międzynarodowych zrzeszeń społeczności lokalnych i regionalnych oraz współpracy ze społecznościami lokalnymi i regionalnymi innych państw zagwarantowała jednostkom samorządu terytorialnego Konstytucja $R P^{11} \mathrm{w}$ art. 172 ust. 2. Jednak inicjatywy w tym zakresie podejmowane mogły być wówczas tylko przez gminy i to w ograniczonym zakresie wynikającym z braku prawnego uregulowania zasad przystępowania gmin (później również pozostałych jednostek samorządu terytorialnego) do organizacji międzynarodowych. Obecnie możliwość podejmowania międzylokalnej i międzyregionalnej współpracy zagranicznej zapewniają ustawy samorządowe ${ }^{12}$, a zasady, na jakich gminy, powiaty i samorządowe województwa mogą przystępować do zrzeszeń międzynarodowych określa ustawa z dnia 15 września 2000 r. o zasadach przystępowania jednostek samorządu terytorialnego do międzynarodowych zrzeszeń społeczności lokalnych i regionalnych (dalej: u.z.p.m.z) ${ }^{13}$. Instrumenty współpracy zagranicznej samorządu terytorialnego zostały jeszcze rozszerzone ustawą z dnia 7 listopada 2008 r. o europejskim ugrupowaniu współpracy terytorialnej (dalej: u.e.u.w.t.) ${ }^{14}$ przyjętą w celu wykonania postanowień rozporządzenia (WE) nr 1082/2006 Parlamentu Europejskiego i Rady z dnia 5 lipca 2006 r. w sprawie europejskiego ugrupowania współpracy terytorialnej (EUWT) $)^{15}$.

Już treść samej ustawy o zasadach przystępowania jednostek samorządu terytorialnego do międzynarodowych zrzeszeń społeczności lokalnych i regionalnych okazała się na tyle innowacyjna, że jej przyjęcie poprzedziły wieloletnie dyskusje, wiele też kontrowersji i sporów budziła procedura legislacyjna. Do tej pory jeszcze jest dyskusyjne, czy ustawodawca zapewnił - w należyty sposób - prawa społeczności lokalnych i regionalnych do współdziałania z ich zagranicznymi odpowiednikami. Coraz częściej pojawiają się głosy, że treść ustawy o zasadach przystępowania jednostek samorządu terytorialnego do międzynarodowych zrzeszeń społeczności lokalnych i regionalnych nie przystaje do współczesnych

${ }^{10}$ S. Dołzbłasz, A. Raczyk, Wspótpraca transgraniczna w Polsce po akcesji do UE, Warszawa 2010, s. 21.

${ }^{11}$ Konstytucja Rzeczypospolitej Polskiej z dnia 2 kwietnia 1997 r. (Dz. U. nr 78, poz. 483 ze zm.).

12 Ustawa z dnia 8 marca 1990 r. o samorządzie gminnym (tekst jedn. Dz. U. z 2013 r. poz. 594 ze zm.), ustawa z dnia 5 czerwca 1998 r. o samorządzie powiatowym (tekst jedn. Dz. U. z 2013 r. poz. 595 ze zm.), ustawa z dnia 5 czerwca 1998 r. o samorządzie województwa (dalej: u.s.w.); tekst jedn. Dz. U. z 2013 r. poz. 596 ze zm.

13 Dz. U. nr 91, poz. 1009 ze zm.

${ }_{14}$ Dz. U. nr 218, poz. 1390 ze zm.

15 Dz. Urz. UE L 210, s. 19, dalej jako rozporządzenie (WE) nr 1082/2006. Zob. także rozporządzenie Parlamentu Europejskiego i Rady (UE) nr 1302/2013 z dnia 17 grudnia 2013 r. zmieniające rozporządzenie (WE) nr 1082/2006 w sprawie europejskiego ugrupowania współpracy terytorialnej (EUWT) w celu doprecyzowania, uproszczenia i usprawnienia procesu tworzenia takich ugrupowań oraz ich funkcjonowania (Dz. Urz. UE L 347, s. 303). 
uwarunkowań, a ponadto budzi uzasadnione wątpliwości natury interpretacyjnej i celowościowej ${ }^{16}$. Pewna niekonsekwencja pojawia się już w samej definicji zrzeszenia zawartej w art. 1 ust. 2 u.z.p.m.z., zgodnie z którym przez międzynarodowe zrzeszenia społeczności lokalnych i regionalnych rozumie się organizacje, związki i stowarzyszenia powoływane przez społeczności lokalne co najmniej dwóch państw zgodnie z ich prawem wewnętrznym. $Z$ tej definicji wynika, że samorząd województwa (społeczność regionalna) nie uczestniczy bezpośrednio w tych międzynarodowych zrzeszeniach.

W doktrynie pojawił się zarzut dotyczący przekroczenia granic konstytucyjnie ustalonej delegacji z art. 172 ust. 3, w którym przekazano do regulacji ustawowej ,zasady”, na jakich jednostki samorządu terytorialnego mogą korzystać z prawa zrzeszania się w strukturach międzynarodowych, ale już nie - określone obecnie w ustawie - obowiązki, które te jednostki powinny spełnić przed aktem ostatecznego przystąpienia do organizacji międzynarodowej ${ }^{17}$. Wątpliwości budzi także fakt, że ustawa reguluje tylko jedną z kwestii, do których odnosi się delegacja zawarta $w$ art. 172 ust. 3 Konstytucji, tj. przystępowania do międzynarodowych zrzeszeń społeczności lokalnych i regionalnych. Druga natomiast, dotycząca bezpośredniej współpracy ze społecznościami lokalnymi i regionalnymi innych państw, pozostaje nieokreślona ustawowo. Te zagadnienia regulują konwencje międzynarodowe, w szczególności konwencja madrycka, a także porozumienia dwustronne między podmiotami występującymi po obu stronach granicy, których zawierania wymaga specyfika takiej współpracy ${ }^{18}$.

Ważne pozostaje jednak, że od powołania samorządu województwa najaktywniejszymi wspólnotami samorządowymi w transgranicznych kontaktach zagranicznych stały się regiony, dla których ustawa o samorządzie województwa przewiduje najbardziej rozwinięte formy prawne współpracy zagranicznej. O ile gminy i powiaty zasadniczo przystępują do międzynarodowych zrzeszeń, o tyle pojemniejsza jest ustawowa koncepcja zagranicznej współpracy przewidziana dla województw samorządowych. Współpraca województwa z organizacjami międzynarodowymi i regionami innych państw stanowi o tyle ważne zadanie tej jednostki, że służy nadrzędnym celom jej działania dotyczącym formułowania strategii rozwoju województwa i realizacji polityki jego rozwoju. Wykazuje ponadto swoistą zależność z polityką regionalną UE, której jednym z głównych

${ }^{16}$ R. Bucholski, Europejskie ugrupowanie wspótpracy terytorialnej (EUWT) jako międzynarodowa forma wspótpracy jednostek samorzadu terytorialnego, [w:] J. Sługocki (red.), Samorzad terytorialny w Polsce $i$ w Europie. Doświadczenia i dylematy dalszego rozwoju, Bydgoszcz 2009, s. 353.

${ }^{17}$ R. Sowiński, Udziat polskich samorzadów $w$ zrzeszeniach międzynarodowych, „Samorząd Terytorialny" 2002, nr 6, s. 29.

${ }_{18}$ M. Woźniak, Wspótpraca międzynarodowa jednostek samorządu terytorialnego w świetle prawa polskiego i standardów międzynarodowych, „Samorząd Terytorialny” 2005, nr 4, s. 18-19. 
celów, finansowanych z Europejskiego Funduszu Rozwoju Regionalnego (również w nowym okresie programowania 2014-2020), jest europejska współpraca terytorialna. W ramach tego celu wsparciu podlega współpraca transgraniczna, transnarodowa oraz międzyregionalna ${ }^{19}$. W tym zakresie nowym instrumentem jest program Europejskiej Współpracy Terytorialnej, na przystąpienie do którego wyraża zgodę Rada Ministrów, przyjmowany przez Komisję Europejską ${ }^{20}$.

Zgodnie z art. 18 pkt 13 i 14 u.s.w. uchwalanie „Priorytetów współpracy zagranicznej województwa" oraz podejmowanie uchwał w sprawie uczestnictwa w międzynarodowych zrzeszeniach regionalnych i innych formach współpracy regionalnej należy do wyłącznej właściwości sejmiku województwa. Obligatoryjny charakter współpracy zagranicznej regionu wynika z art. 41 ust. 2 pkt 5 u.s.w. stanowiącego, że do zadań zarządu województwa należy m.in. organizowanie współpracy ze strukturami samorządu regionalnego w innych krajach i z międzynarodowymi zrzeszeniami regionalnymi. W ustawie o samorządzie województwa wprowadzony jest zresztą odrębny rozdział (VI) poświęcony współpracy zagranicznej, z którego wywodzi się konkretne obowiązki i zadania polskich regionów. Można zgodzić się z tym, że odzwierciedla to ogólniejszą tendencję kształtowania się koncepcji Europy Regionów oraz rozwoju regionalnej współpracy transgranicznej, zwłaszcza w obrębie euroregionów. Z drugiej jednak strony nie sposób nie zauważyć dużej ostrożności ustawodawcy kierującego się konstytucyjną zasadą jednolitości państwa oraz wyrażanymi w 1998 r. obawami przed nadmierną samodzielnością województw ${ }^{21}$.

Wolą prawodawcy współpraca zagraniczna samorządu województwa pozostaje - i to jeszcze na etapie jej planowania - pod kontrolą administracji rządowej. Znamienne okazują się także postanowienia Konstytucji, w myśl których obywatelom przysługuje ,wolność” zrzeszania się, zaś dla samorządu przewidziano jedynie prawo przystępowania do zrzeszeń2 ${ }^{2}$. Ponadto, w odniesieniu do działalności polskich regionów odchodzi się od używania terminu współpraca międzynarodowa. Chociaż ich aktywność w kontaktach zagranicznych jest zbliżona do stosunków międzynarodowych, to jednak w świetle prawa międzynarodowego publicznego jednostki te nie mają podmiotowości. W odróżnieniu od części składowych państw federalnych (stanów, landów, krajów związkowych czy kantonów) samorząd województwa nie dysponuje nawet częścią suwerenności

19 Art. 2 rozporządzenia Parlamentu Europejskiego i Rady (UE) nr 1299/2013 z dnia 17 grudnia 2013 r. w sprawie przepisów szczegółowych dotyczących wsparcia z Europejskiego Funduszu Rozwoju Regionalnego w ramach celu „Europejska współpraca terytorialna” (Dz. Urz. UE L 347, s. 259).

${ }^{20}$ Art. 2 pkt 17 lit. b ustawy z dnia 11 lipca 2014 r. o zasadach realizacji programów w zakresie polityki spójności finansowanych w perspektywie finansowej 2014-2020 (Dz. U. poz. 1146).

${ }^{21}$ H. Izdebski, Samorząd terytorialny. Podstawy ustroju i działalności, Warszawa 2006, s. 301.

${ }^{22}$ H. Zięba-Załucka, Wspótpraca międzynarodowa samorządów, „Samorząd Terytorialny” 2008, nr 1-2, s. 65. 
państwowej, nie może też zawierać umów międzynarodowych. Dla porównania landy niemieckie, na mocy ustawy zasadniczej RFN z 1949 r., upoważnione są - za zgodą rządu federalnego - do dokonywania transferu praw zwierzchnich na rzecz instytucji transgranicznych w sąsiednich regionach, a Federalna ustawa konstytucyjna Republiki Austrii z 1920 r. uprawnia landy do zawierania umów z graniczącymi z Austrią państwami lub ich częściami składowymi.

W polskim prawie i piśmiennictwie występuje pojęcie współpraca zagraniczna województw czy - przyjęte z prawa europejskiego, w tym prawa Unii Europejskiej - określenia europejskiej współpracy terytorialnej, w tym transgranicznej (przygranicznej), transregionalnej (międzyregionalnej). Kryterium rozróżnienia stanowi sąsiedzkość podmiotów współpracujących przez granicę państwową lub jej brak, gdy jednostki współpracujące nie sąsiadują ze sobą bezpośrednio - obszar współpracy nie jest ciągły 23 . W tym drugim przypadku wyraźne wykazanie interesu publicznego w podejmowaniu współpracy zagranicznej wydaje się szczególnie pożądane. Zawieranie umów z partnerami z odległych państw bez wskazania określonej wartości dla społeczności lokalnych czy regionalnych nie przystaje bowiem do ustrojowoprawnej koncepcji samorządu terytorialnego ${ }^{24}$.

Prezentowane są zróżnicowane poglądy na temat udziału regionów europejskich w polityce transgranicznej. Raz uważa się taką działalność za „,paradyplomację" podejmowaną dla wyeksponowania swoistej niezależności regionów w procesie kształtowania współpracy z innymi jednostkami w sąsiednich państwach $^{25}$. Innym razem działalność transgraniczna regionów traktowana jest jako pewna subsydiarna forma narodowej polityki zagranicznej, będąca elementem polityki wykonywanej przez rząd centralny i realizowana na podstawie priorytetów państwa ${ }^{26}$. Wydaje się, że prowadzona w tym obszarze dyskusja jest przejawem szerszego - dotąd nierozstrzygniętego - sporu między zwolennikami zwiększenia kompetencji regionów w procesie integracji europejskiej (koncepcji Europy Regionów, współcześnie zastępowanej koncepcją Europy z regionami) a zwolennikami pozostawienia w tym zakresie roli głównego decydenta państwu narodowemu (koncepcji Europy Ojczyzn). Odzwierciedleniem tego są chociażby problemy z przyjęciem Europejskiej Karty Samorządu Regionalnego z 1988 r.

${ }^{23}$ M. Perkmann, Building Governance Institutions Across European Borders, „Regional Studies" 1999, vol. 33.7, s. 657-667.

${ }^{24}$ R. Kusiak-Winter, Wspótpraca jednostek samorzadu terytorialnego ze społecznościami lokalnymi i regionalnymi innych państw w świetle problematyki dychotomicznego podziału państwa, [w:] S. Wrzosek i in. (red.), Przeglad dyscyplin badawczych pokrewnych nauce prawa i postępowania administracyjnego, Lublin 2010, s. 33.

25 P. Soldatos, An Explanatory Framework for the Study of Federated States and Foreign Policy Actors, [w:] H.J. Michelmann, P. Soldatos (eds.), Federalism and International Relations - The Role of Subnational Units, Oxford 1990, s. 34-53.

${ }_{26}$ Zob. K. Tomaszewski, Regiony w procesie integracji europejskiej, Kraków 2007, s. 104. 
i kolejnej jej wersji z 1997 r., która - mimo ponawianych w 2005 i 2007 r. prób ratyfikacji, dotąd nie uzyskała zgody większości państw na nadanie mocy wiążącej i pozostaje wciąż nieobowiązującym projektem. Z punktu widzenia odmiennych form ustrojowych państw, innych tradycji narodowych, różnych typów regionów (nawet w ramach jednego państwa) i wynikającego stąd innego zakresu ich władzy, w tym dotyczącej podejmowania współpracy zagranicznej, wiele postanowień Karty okazało się sprzeczne z interesem części państw.

Podobne wątpliwości pojawiły się na etapie kształtowania nowego instrumentu współpracy terytorialnej w postaci EUWT, z siedzibą na terytorium Wspólnoty, przyznaną zdolnością prawną i zdolnością do czynności prawnych o najszerszym zakresie przyznawanym osobom prawnym na mocy prawa państwa członkowskiego. Jest to forma pozwalająca utworzyć ponadnarodowy podmiot prawa publicznego, który może przejąć od swoich uczestników ich zadania, otrzymać składniki ich mienia i tworzyć jednostki organizacyjne oraz zatrudniać pracowników, wreszcie występować jako strona w postępowaniu sądowym. EUWT jest nowością pod tym względem, że umożliwia stowarzyszanie samorządów różnych państw członkowskich UE bez konieczności podpisywania umów międzynarodowych. Warto jednak zwrócić uwagę, że podejmowanie współpracy jest w tym wypadku dopuszczone nawet $\mathrm{z}$ państwami niebędącymi członkami UE, np. Polski z Ukrainą. W sprawach nieuregulowanych lub częściowo uregulowanych w rozporządzeniu (WE) nr 1082/2006 do ugrupowania stosuje się prawo państwa członkowskiego, w którym znajduje się siedziba statutowa EUWT. Zdaje się przez to tworzyć bardzo mocna pozycja członków ugrupowania pochodzących z państwa, w którym EUWT ma swoją siedzibę. Dysproporcję równowagi między członkami pogłębia jeszcze brak możliwości przeniesienia siedziby statutowej ugrupowania ${ }^{27}$.

Jakkolwiek powstanie EUWT było odpowiedzią na problemy wynikające ze zróżnicowania systemów prawnych zagranicznej współpracy terytorialnej w poszczególnych państwach członkowskich UE, projekt rozporządzenia w tej sprawie długo postrzegany był jako kontrowersyjny. Rewolucyjna treść aktu ukryta była w pozornie prostym założeniu zawartym w art. 3 ust. 1, zgodnie z którym ugrupowanie składa się z członków w granicach kompetencji przyznanych im na mocy prawa krajowego. Z tego sformułowania wywodzono, że potencjalnym członkom ugrupowania, w tym państwom narodowym, władzom regionalnym i lokalnym oraz innym podmiotom prawa publicznego, przysługuje zdolność prawna do zawarcia umowy ze swoimi partnerami zagranicznymi, mogącej wpływać na stosunki zagraniczne państw. W tym aspekcie zwłaszcza działania regionów można byłoby traktować jako aktywność międzynarodową sensu stricto, polegającą na

27 A. Bussmann, Europejskie ugrupowanie wspótpracy terytorialnej (EUWT) - przełom we wspótpracy transgranicznej w Unii Europejskiej?, „Samorząd Terytorialny” 2008, nr 10, s. 15. 
prowadzeniu polityki zagranicznej „ubocznej”, a w przypadku niektórych regionów europejskich ujawniającą nawet aspiracje do samodzielnego funkcjonowania. Dopiero zagwarantowanie wpływu państw członkowskich na utworzenie ugrupowania $\mathrm{w}$ formie wyrażanej przez nie zgody będącej warunkiem sine qua non uczestnictwa danego podmiotu w EUWT, pozwoliła na przyjęcie nowego instrumentu współpracy transgranicznej w Unii Europejskiej ${ }^{28}$.

W Polsce istotne ograniczenia samorządu województwa w obszarze współpracy zagranicznej wynikają z wyłącznych kompetencji Prezydenta RP oraz Rady Ministrów do prowadzenia polityki zagranicznej państwa. W związku z tym ustawodawca słusznie zastrzegł, że samorząd województwa podejmuje współpracę ze społecznościami regionalnymi innych państw zgodnie z prawem wewnętrznym, polityką zagraniczną państwa i jego międzynarodowymi zobowiązaniami oraz w granicach swoich zadań i kompetencji (art. 76 ust. 1 u.s.w.). O ile uchwały sejmiku województwa zapadają - co do zasady - zwykłą większością głosów ustawowego składu organu, to w odniesieniu do wszelkich uchwał dotyczących współpracy zagranicznej wprowadzony został wymóg bezwzględnej większości głosów.

Wypada podzielić pogląd, zgodnie z którym interes państwa jest ważny na tyle, że konieczne jest zagwarantowanie bezpośredniego wpływu państwa na wykonywanie prawa przystępowania do międzynarodowych zrzeszeń przez jednostki samorządu terytorialnego ${ }^{29}$. Zrzeszenie, którego działalność lub polityka odstaje w jakimkolwiek stopniu od polityki zagranicznej RP lub też stanowi przeszkodę w wywiązywaniu się z zaciągniętych zobowiązań międzynarodowych, nie może być partnerem dla polskiego stowarzyszenia jednostek samorządu terytorialne$\mathrm{go}^{30}$. Powstać może jednak pytanie czy niektóre środki prawne oddziaływania państwa na kształt współpracy zagranicznej samorządu województwa nie ograniczają jego samodzielności ustrojowej. Część rozwiązań prawnych przyjętych - zdaniem niektórych autorów - w celu uniemożliwienia pojawiania się działań separatystycznych ${ }^{31}$, budzić musi wątpliwości. Znaczącą trudność stanowią także nieprecyzyjne przepisy mogące $\mathrm{w}$ praktyce prowadzić do niejednolitej interpretacji, do tego rozproszone w odrębnych aktach prawnych. W świetle chronionego konstytucyjnie prawa wszystkich jednostek samorządu terytorialnego przystę-

${ }^{28}$ Zob. A. Bussmann, Instrumenty wspólpracy transgranicznej $w$ świetle międzynarodowego prawa publicznego (traktat z Karlsruhe) i prawa europejskiego, [w:] K. Nowacki, R. Russano (red.), Prawne problemy regionalizacji w Europie, Wrocław 2008, s. 321-322.

29 A. Wiktorowska, Prawne determinanty samodzielności gminy-zagadnienia administracyjnoprawne, Warszawa 2002, s. 117.

${ }^{30}$ R. Cybulska, Komentarz do art. 76, [w:] B. Dolnicki (red.), Ustawa o samorzadzie województwa. Komentarz, Warszawa 2012, s. 585.

${ }^{31} \mathrm{~S}$. Iwanowski, P. Sitniewski, Znaczenie porozumień administracyjnych $w$ nowych warunkach ustrojowych samorzadu terytorialnego, [w:] S. Dolata (red.), Prawne i finansowe aspekty funkcjonowania samorzadu terytorialnego, t. I, Prawo samorzadowe i administracyjne, Opole 2000, s. $169-170$. 
powania do międzynarodowych zrzeszeń społeczności lokalnych i regionalnych oraz współpracy z tymi społecznościami, błędne wydaje się już samo ograniczenie w ustawie o samorządzie województwa zrzeszania i współpracy tylko do szczebla regionalnego ${ }^{32}$.

Podstawę współpracy zagranicznej samorządu regionalnego stanowi uchwała sejmiku w sprawie „Priorytetów współpracy zagranicznej województwa” określająca główne cele tej współpracy, jej priorytety geograficzne oraz zamierzenia co do przystąpienia do międzynarodowych zrzeszeń regionalnych. Jak stanowi art. 77 ust. 1 u.s.w. „Priorytety współpracy zagranicznej województwa” mogą być uchwalane oraz inicjatywy zagraniczne województwa, w tym w szczególności projekty umów o współpracy regionalnej, mogą być podejmowane za zgodą ministra właściwego do spraw zagranicznych. Bez uzyskania tej zgody nie jest możliwe skuteczne podjęcie uchwały w sprawie nawiązania przez województwo współpracy międzyregionalnej. Zgoda obejmuje bowiem nie tylko samo zawarcie porozumienia, ale również jego treść. Jeśli treść ta wykracza poza treść ustaloną w wydanej przez ministra zgodzie, oznacza to pominięcie obowiązku uzyskania zgody ministra w zakresie wykraczającym poza udzieloną zgodę. Odstąpienie od powyższego obowiązku jest tożsame $\mathrm{z}$ istotnym naruszeniem prawa ${ }^{33}$.

Nie jest do końca jasne, na jakim etapie zgoda ma być wyrażana. Z art. 77 ust. 1 u.s.w. wyraźnie wynika, że jest to jeszcze etap planowania współpracy zagranicznej przez samorząd województwa. Dylemat pojawić się może jednak na tle art. 77 ust. 3 u.s.w. stanowiącego, że ,uchwała oraz zawarte umowy o współpracy regionalnej, o których mowa w ust. 1, przesyłane są przez marszałka województwa do ministra właściwego do spraw zagranicznych oraz ministra właściwego do spraw administracji publicznej”. W tym przepisie chodzi o już obowiązujące uchwały i umowy, których przekazanie należy wiązać raczej z wprowadzonym tu dodatkowym obowiązkiem informacyjnym, a nie z obowiązkiem uzyskania zgody ministra. Pomimo tego, że podjęte uchwały i zawarte umowy były już wcześniej oceniane przez ministra właściwego do spraw zagranicznych, podlegają przekazaniu temu ministrowi oraz ministrowi właściwemu do spraw administracji publicznej. Niemniej pozostaje pewna niejasność dotycząca etapu wyrażania zgody przez ministra.

Nasuwa się też pytanie o celowość wprowadzania odmiennych rozwiązań prawnych w odniesieniu do obowiązku przekazywania uchwał, umów czy ich projektów różnym organom. Uchwała o przystąpieniu do międzynarodowego zrzeszenia przekazywana jest ministrowi właściwemu do spraw zagranicznych za pośrednictwem wojewody, dołączającego swoją opinię (art. 4 ust. 3 u.z.p.m.z.).

${ }^{32}$ Tak też S. Czarnow, Wspótpraca zagraniczna województw, „Państwo i Prawo” 2000, z. 11 , s. 61 .

${ }^{33}$ Rozstrzygnięcie nadzorcze Wojewody Dolnośląskiego z dnia 4 czerwca 2001 r., PN.II.0911-3 /14/01, „Orzecznictwo w Sprawach Samorządowych” 2001, nr 4, poz. 127. 
Z kolei w ustawie o europejskim ugrupowaniu współpracy terytorialnej brak jest odpowiednich przepisów w tym zakresie. $\mathrm{Z}$ uwagi na wymóg zgody ministra właściwego do spraw zagranicznych na przystąpienie samorządu województwa do ugrupowania, uchwała powinna być niewątpliwie przesłana ministrowi, ale czy w tym przypadku także za pośrednictwem wojewody? W związku z obowiązkiem marszałka województwa przedkładania uchwał sejmiku i zarządu odpowiednio wojewodzie/regionalnej izbie obrachunkowej, których nadzór nie został tu przecież wyłączony, wszelkie uchwały sejmiku województwa w sprawach współpracy zagranicznej podlegają jeszcze przekazaniu wojewodzie w terminie siedmiu dni od dnia ich podjęcia.

Nie jest także oczywiste, czy akceptację ministra muszą uzyskać wszystkie inicjatywy zagraniczne, czy tylko podpisywane umowy i podobne dokumenty ${ }^{34}$. Ustawowy katalog inicjatyw ma niewątpliwie otwarty charakter. $Z$ tego punktu widzenia należy założyć, że akceptacja zawsze będzie wymagana, niemniej w praktyce wymóg każdorazowej zgody ministra może okazać się problemowy w działaniach niemających jeszcze dużej rangi, jak np. przy listach intencyjnych, deklaracjach czy ustnych porozumieniach. Rozważenia wymaga propozycja interpretacji art. 77 ust. 1 u.s.w. w zw. z art. 6 u.s.w. Zwrot „w szczególności projekty umów” należałoby wówczas zestawić z obowiązkiem przedstawiania ministrowi projektów tych inicjatyw zagranicznych, które mogą wywoływać bezpośrednie skutki prawne. Przy takiej interpretacji zgody nie wymagałaby np. wymiana delegacji zagranicznej oraz inne podobne przedsięwzięcia wynikające z uprzednio określonych celów współpracy $^{35}$. Nasuwa się jednak pytanie o istnienie skutków prawnych w odniesieniu do inicjatyw zagranicznych samorządu województwa. Zdaniem niektórych autorów w tym przypadku można mówić nie o skutkach prawnych, lecz o skutkach politycznych lub społecznych. Inicjatywy te, w tym umowy o współpracy regionalnej nie mają bowiem charakteru prawnomiędzynarodowego ${ }^{36}$.

Należy zauważyć, że w ustawie o samorządzie województwa nie został nawet sprecyzowany status uchwały mającej podstawowe znaczenie dla kształtu przyszłej współpracy zagranicznej województwa. W literaturze nie ma w tej kwestii zgodności. Jednym razem zajmowane jest stanowisko, że „Priorytety współpracy zagranicznej województwa" są jedynie dokumentem programowym, określającym cel, charakter i obszar geograficzny zamierzonych inicjatyw zagranicznych samorządu województwa ${ }^{37}$, że stanowią w istocie deklarację intencji sejmiku jako politycznej reprezentacji województwa ${ }^{38}$. Innym razem uchwała sejmiku $\mathrm{w}$ tej

${ }^{34}$ S. Dołzbłasz, A. Raczyk, Wspótpraca transgraniczna ..., s. 24.

${ }_{35}$ W. Sokolewicz, Komentarz do ustawy o samorzadzie województwa, Warszawa 2000, s. 62.

${ }^{36}$ K. Jóskowiak, Wspótpraca transgraniczna i międzyregionalna Polski u progu członkostwa w Unii Europejskiej, „Samorząd Terytorialny” 2003, nr 5, s. 12.

${ }^{37}$ W. Sokolewicz, Komentarz do ustawy..., s. 62.

38 S. Czarnow, Wspótpraca zagraniczna..., s. 63. 
sprawie określana jest jako szczególny akt prawa miejscowego, z jednej strony zawierający normy prawne skierowane do organów samorządu województwa, $\mathrm{z}$ drugiej - regulujący zasady postępowania w stosunkach zewnętrznych ${ }^{39}$. Problem jest $\mathrm{w}$ istocie złożony. Wysoka ranga tej uchwały wynika choćby $\mathrm{z}$ tego, że od zgodności z „Priorytetami” zależy przystąpienie województwa do międzynarodowego zrzeszenia. Województwo nie może przystąpić do zrzeszenia, jeśli w „Priorytetach” nie przewidziano odpowiedniego zamierzenia w tej kwestii.

Dla ustalenia charakteru „Priorytetów” istotna będzie jednak odpowiedź na pytanie o relacje treści uchwały sejmiku województwa do działalności podmiotów niepowiązanych organizacyjnie ze strukturą samorządu regionalnego. Założenia „Priorytetów współpracy zagranicznej województwa” w jakimś sensie są adresowane do różnych kreatorów rozwoju województwa, w tym władz samorządu lokalnego, podmiotów wspierających przedsiębiorczość, publicznych i prywatnych inwestorów, organizacji pozarządowych, społecznych, szkół i jednostek naukowo-badawczych, a nawet współpracujących podmiotów zagranicznych. Nie sposób jednak nie zgodzić się z tym, że o ile dla działań organów samorządu województwa „Priorytety” stanowią podstawę bezpośrednią w tych dziedzinach i w tych zakresach, które wynikają z kompetencji samorządu, to na podmioty autonomiczne oddziałują już tylko pośrednio (informacyjnie, inspiracyjnie, organizacyjnie i pomocowo), tak aby współuczestniczyły one w zagranicznej współpracy regionalnej ${ }^{40}$. Takie pośrednie oddziaływanie nie jest jeszcze wystarczające do uznania określonej uchwały za akt normatywny w rozumieniu art. 87 ust. 2 Konstytucji RP.

Współczesny model prawny współpracy zagranicznej województwa charakteryzuje się rozproszeniem instytucjonalnych form tej współpracy w różnych aktach prawnych. Na gruncie rozdziału VI ustawy o samorządzie województwa można mówić o dwóch takich formach, chociaż i tu ustawodawca nie zadbał o dostateczną precyzję. Obok przystępowania do międzynarodowych zrzeszeń, pojawia się uczestnictwo $\mathrm{w}$ działalności międzynarodowych instytucji regionalnych. Województwo jest w nich reprezentowane na zasadach określonych w porozumieniu zawartym przez ogólnokrajowe organizacje zrzeszające jednostki samorządu terytorialnego (art. 76 ust. 2 u.s.w.). Od 2002 r. interesy wszystkich polskich województw samorządowych reprezentuje Związek Województw RP ${ }^{41}$. Brak ustawowej definicji „międzynarodowych instytucji regionalnych” utrudnia jednak wskazanie ich wyczerpującego katalogu. W doktrynie tylko przykładowo

${ }^{39}$ K. Bandarzewski, Wspótpraca zagraniczna, [w:] P. Chmielnicki (red.), Komentarz do ustawy o samorządzie województwa, Warszawa 2005, s. 365.

${ }^{40}$ K. Jóskowiak, Wspótpraca transgraniczna..., s. 15.

${ }^{41}$ Art. 3 ust. 1 pkt 3 ustawy z dnia 6 maja 2005 r. o Komisji Wspólnej Rządu i Samorządu Terytorialnego oraz o przedstawicielach Rzeczypospolitej Polskiej w Komitecie Regionów Unii Europejskiej (Dz. U. nr 90, poz. 759). 
zalicza się do tych instytucji Izbę Regionów wchodzącą, obok Izby Władz Lokalnych, w skład Kongresu Władz Lokalnych i Regionalnych będącego organem Rady Europy, a także unijny Komitet Regionów ${ }^{42}$. W obu Związek Województw RP ma swoich reprezentantów. Dodać jednak warto, że wyrazem wyraźnie rosnącego politycznego znaczenia współpracy zagranicznej między regionami jest działalność również takich organizacji, jak Zgromadzenie Regionów Europy (od 1987 r.), Rada Gmin i Regionów Europy (od 1984 r.), Stowarzyszenie Europejskich Regionów Przygranicznych (od 1971 r.) czy Konferencja Peryferyjnych Regionów Nadmorskich Wspólnoty Europejskiej (od 1973 r.).

Szczególne i chyba największe kontrowersje budzi instytucja zgody ministra właściwego do spraw zagranicznych wymagana zarówno na uchwalenie „Priorytetów", podejmowanie inicjatyw zagranicznych (art. 77 ust. 1 u.s.w.), jak i na przystąpienie województwa do międzynarodowego zrzeszenia społeczności lokalnych i regionalnych, jego współtworzenie czy dalsze członkostwo w zrzeszeniu - w przypadku zmiany jego celów lub zasad działania (art. 4 ust. 5, art. 8 i art. 10 ust. 1 u.z.p.m.z.), wreszcie na przystąpienie do europejskiego ugrupowania współpracy terytorialnej (art. 6 ust. 1 u.e.u.w.t.). W odniesieniu do tej działalności uchwałodawczej sejmiku województwa przewidziany został zatem szczególny środek nadzoru, któremu można nadać - jak się wydaje - charakter quasi-aktu nadzoru. Trudno traktować ten akt jako formę współdziałania sejmiku województwa i ministra stanowiących niejako organy współkompetentne przy podejmowaniu współpracy zagranicznej przez województwo ${ }^{43}$. Jak wynika chociażby z art. 5 u.z.p.m.p. czynność prawna podjęta z naruszeniem art. 4 (w tym wprowadzającego wymóg zgody ministra na przystąpienie do zrzeszenia oraz wymóg wejścia w życie uchwały dopiero po uzyskaniu tej zgody) jest nieważna z mocy prawa. Jest to nieważność bezwzględna i dotycząca każdego z elementów czynności, ma skutek erga omnes i nie wymaga oświadczeń potwierdzających ${ }^{44}$. Nie ulega wątpliwości, że wyrażenie zgody jest warunkiem ważności uchwały organu stanowiącego, a zatem prewencyjnym (ex ante) środkiem nadzoru ad meritum ${ }^{45}$.

O ile jednak sama treść aktu (zgoda/odmowa, cofnięcie zgody) przesądza w tym przypadku o wystąpieniu typowego rozstrzygnięcia nadzorczego, to minister nie jest przecież organem nadzoru nad działalnością jednostek samorządu terytorialnego. Należy podzielić pogląd M. Kasińskiego, że w świetle Konstytucji i ustaw ustrojowych nie jest uprawnione rozszerzenie kręgu organów nadzorujących samorząd i ograniczenie w ten sposób jego konstytucyjnie zagwaranto-

${ }^{42}$ H. Izdebski, Samorzad terytorialny ..., s. 305-306.

${ }^{43}$ Tak: S. Czarnow, Wspótpraca zagraniczna ..., s. 62; P. Jankowski, Nadzór nad samorządem województwa, „Przegląd Prawa Publicznego” 2010, nr 12, s. 50.

${ }^{44} \mathrm{R}$. Sowiński, Ustawowa regulacja udziału jednostek samorzadu terytorialnego w międzynarodowych zrzeszeniach społeczności lokalnych, „Samorząd Terytorialny” 2002, nr 7-8, s. 38.

45 J. Korczak, K. Nowacki, Współdziałanie komunalne i regionalne $w$ obszarze przygranicznym. Euroregiony polskie, [w:] K. Nowacki, R. Russano (red.), Prawne problemy..., s. 345. 
wanej samodzielności. W tym obszarze kompetencje typu nadzorczego powinny przysługiwać Prezesowi Rady Ministrów ${ }^{46}$. W doktrynie proponuje się też - zasługujące na rozważenie wprowadzenia - rozwiązanie, zgodnie z którym minister właściwy do spraw zagranicznych dokonywałby wyłącznie wstępnej oceny proponowanej uchwały czy planowanej inicjatywy zagranicznej województwa, przedstawiając Prezesowi Rady Ministrów projekt określonego rozwiązania w tym zakresie. Do wyrażenia albo odmowy wyrażenia stosownej zgody byłby jednak kompetentny Prezes Rady Ministrów ${ }^{47}$.

Zgoda, odmowa czy cofnięcie zgody ministra na przystąpienie województwa do międzynarodowego zrzeszenia oraz do europejskiego ugrupowania następuje $\mathrm{w}$ formie decyzji administracyjnej, mimo że akt ten nie rozstrzyga $\mathrm{w}$ tych wypadkach indywidualnej sprawy z zakresu administracji publicznej. Nie jest również zgodą (stanowiskiem, opinią) w rozumieniu art. 106 k.p.a. ${ }^{48} \mathrm{~W}$ piśmiennictwie podkreśla się, że jest to jeden z przykładów zbyt dowolnego użycia pojęcia decyzji administracyjnej przez ustawodawcę ${ }^{49}$. Wprost podnoszony jest też w tym aspekcie problem ograniczenia samodzielności uchwałodawczej samorządu wynikający z tego, że uchwały organu stanowiącego dotyczące przystąpienia do międzynarodowego zrzeszenia, jak i do europejskiego ugrupowania wchodzą w życie dopiero po wyrażeniu stosownej zgody przez ministra. Przystąpienie województwa do zrzeszenia czy ugrupowania jest w swej istocie dobrowolne, powinno następować zawsze z inicjatywy samorządu regionalnego. Sama jednak wola przystąpienia do tych organizacji okazuje się być niewystarczająca z uwagi na wymóg zgody ministra ${ }^{50}$.

Zdania na temat charakteru zgody ministra właściwego do spraw zagranicznych są podzielone. Niektórzy autorzy uważają, że wyrażenie tej zgody nie następuje w ramach uznania administracyjnego, bo minister jest obowiązany wydać zgodę, jeśli planowana przez województwo współpraca odpowiada warunkom określonym $\mathrm{w}$ art. 76 u.s.w., tzn. mieści się w granicach zadań i kompetencji województwa oraz pozostaje w zgodzie zarówno z prawem wewnętrznym państwa, jak też jego polityką zagraniczną i zobowiązaniami międzynarodowymi ${ }^{51}$.

${ }^{46}$ M. Kasiński, Monizm i pluralizm władzy lokalnej. Studium prawno-polityczne, Łódź 2009, s. 345 .

47 J. Maćkowiak, Wspótpraca międzynarodowa województw - aspekty prawne, „Kontrola Państwowa" 2002, nr 6, s. 41.

${ }^{48}$ Ustawa z dnia 14 czerwca 1960 r. - Kodeks postepowania administracyjnego (tekst jedn. Dz. U. z 2013 r. poz. 267 ze zm.).

49 J. Zimmermann, Prawo administracyjne, Kraków 2006, s. 225.

${ }^{50}$ B. Jaworska-Dębska, Współdziałanie $i$, ruch zadań" w systemie samorzadu terytorialnego, [w:] M. Stahl (red.), Prawo administracyjne. Pojeccia, instytucje, zasady w teorii i orzecznictwie, Warszawa 2013, s. 433-434.

51 S. Czarnow, Wspótpraca zagraniczna..., s. 63; K. Bandarzewski, Wspótpraca zagraniczna..., s. 373. 
Podnosi się, że również na uczestnictwo przyszłego członka w EUWT państwo członkowskie ma obowiązek udzielania zgody, chyba że uważa, że takie uczestnictwo, w tym uprawnienia i obowiązki przyszłego członka, nie jest zgodne z rozporządzeniem (WE) nr 1082/2006 lub prawem krajowym, lub też dla takiego uczestnictwa istnieje brak uzasadnienia interesem publicznym lub porządkiem publicznym państwa członkowskiego. W przypadku odmowy udzielenia zgody na uczestnictwo, państwo musi uzasadnić powody nieudzielenia zgody ${ }^{52}$. Brak jasnych przesłanek udzielania tej zgody zdaje się wskazywać jednak na inny charakter udziału ministra w sprawie przystępowania jednostki samorządu terytorialnego do EUWT.

Ten sam autor wyraża jednocześnie obawę, której nie można już zarzucić braku zasadności, że złożona procedura uzyskiwania zgody na przystąpienie do ugrupowania, obarczona często dozą niechęci i obaw urzędników administracji centralnej przed zbyt głęboką decentralizacją, będzie przeszkodą w wykorzystaniu nowego instrumentu współpracy terytorialnej w Polsce ${ }^{53}$. Inną sprawą jest, że tworzenie ugrupowania stanowi kosztowne i czasochłonne przedsięwzięcie, które wymaga dużego zaangażowania i nakładów pracy ${ }^{54}$. W myśl art. 6 ust. 1 u.e.u.w.t. minister właściwy do spraw zagranicznych wyraża zgodę na przystąpienie do europejskiego ugrupowania $\mathrm{w}$ uzgodnieniu $\mathrm{z}$ ministrem właściwym do spraw wewnętrznych, ministrem właściwym do spraw finansów publicznych oraz ministrem właściwym do spraw rozwoju regionalnego. $Z$ tego punktu widzenia nie wydaje się nawet zbyt długi termin 3 miesięcy, jaki ustawodawca wyznaczył ministrowi na podjęcie decyzji. W praktyce województwo może jednak znacznie później przystąpić do ugrupowania. W razie przekroczenia 3-miesięcznego terminu nie jest bowiem przewidziana żadna sankcja, a ugrupowanie mające siedzibę statutową na terytorium w Polsce nabywa osobowość prawną dopiero $\mathrm{z}$ dniem wpisania do rejestru prowadzonego przez ministra właściwego do spraw zagranicznych.

Warto zauważyć, że nie zostały wprost wskazane kryteria udzielania zgody ani sformułowane, nawet przykładowe, przesłanki uzasadniające odmowę wyrażenia zgody na przystąpienie do międzynarodowego zrzeszenia czy europejskiego ugrupowania. Nieznane są wobec tego motywy, jakimi ma kierować się minister, odmawiając tej zgody ${ }^{55}$. Te problemy powstają również w odniesieniu do „Priorytetów współpracy zagranicznej województwa” oraz inicjatyw zagranicznych.

${ }^{52}$ R. Bucholski, Europejskie ugrupowanie..., s. 350-351.

53 Tamże, s. 357.

${ }^{54}$ A. Malinowska, Wspótpraca zagraniczna samorząu województwa-zagadnienia wybrane, „Przegląd Prawa Publicznego" 2012, nr 7-8, s. 147.

${ }_{55}$ M. Ofiarska, Formy publicznoprawne współdziałania jednostek samorzadu terytorialnego, Warszawa 2008, s. 331; K. Wlaźlak, Komentarz do art. 18 ust. 2 pkt 12a, [w:] P. Chmielnicki (red.), Ustawa o samorzadzie gminnym. Komentarz, Warszawa 2013, s. 371. 
W ustawie o samorządzie województwa określone są kryteria współpracy województwa ze społecznościami regionalnymi innych państw, nie zaś konkretne przesłanki, jakimi kieruje się minister wyrażając zgodę (odmowę) na uchwalenie „Priorytetów” oraz podejmowanie inicjatyw zagranicznych. Nawet gdyby je za takie uznać, to szczególnie zgodność współpracy samorządu województwa z polityką zagraniczną państwa stanowiłoby bardzo płynne kryterium nadzoru. Trudno byłoby też podzielić pogląd o związanym charakterze decyzji ministra w świetle art. 10 ust. 2 u.z.p.m.z. Zawarte w tym przepisie sformułowanie: „w przypadku pojawienia się rozbieżności pomiędzy celami polityki zagranicznej państwa a polityką zrzeszenia minister właściwy do spraw zagranicznych może cofnąć zgodę na przystąpienie do zrzeszenia", w istocie jest klasycznym przykładem uznania administracyjnego świadczącym o takim właśnie charakterze decyzji ministra.

Nadmiernie złożona procedura podejmowania współpracy zagranicznej samorządu województwa może wpływać na ograniczenie wykorzystania potencjału polskich regionów w rozwoju tej współpracy. Bez wątpienia obowiązujące w tym zakresie regulacje nie są jednoznaczne, wiele do życzenia pozostawia także spójność przepisów. Te, które znajdują się w ustawie ustrojowej powinny, jak słusznie podnosi J. Maćkowiak, porządkować problematykę współpracy zagranicznej województw, wydzielając i określając różne instytucjonalne formy takiej współpracy oraz regulując kwestie, które pominięte zostały w odrębnych aktach prawnych ${ }^{56}$. Samo ustalenie tych form budzi już poważne trudności. W ustawie o samorządzie województwa wyodrębnia się tylko dwie z nich: uczestnictwo w międzynarodowych zrzeszeniach społeczności regionalnych (czy też raczej społeczności lokalnych i regionalnych) oraz udział w działalności międzynarodowych instytucji regionalnych. W odrębnych ustawach określone są zasady przystępowania do międzynarodowych zrzeszeń oraz do europejskiego ugrupowania współpracy terytorialnej. To ostatnie stanowi kolejną zinstytucjonalizowaną formę współpracy zagranicznej województwa. Jeszcze inną formą - szczegółowo tutaj nie analizowaną - jest współpraca transgraniczna, realizowana zgodnie z konwencją madrycką.

Z konieczności przestrzegania konstytucyjnej zasady jednolitości państwa, wpływ państwa na charakter i formy współpracy zagranicznej podejmowanej przez samorząd województwa jest niewątpliwie potrzebny. W tym kontekście nie budzi wątpliwości samo wprowadzenie instytucji zgody administracji rządowej na uchwalenie „Priorytetów współpracy zagranicznej województwa”, inicjatyw zagranicznych, przystępowanie do międzynarodowych zrzeszeń społeczności lokalnych i regionalnych oraz do EUWT. Dyskusyjna okazuje się jednak kwestia zachowania odpowiednich proporcji między zasadą samodzielności samorządu województwa a zasadą wyłączności państwa do kształtowania i prowadzenia polityki

${ }^{56}$ J. Maćkowiak, Wspótpraca międzynarodowa ..., s. 43. 
zagranicznej. Niektóre środki prawne przyjęte przez polskiego ustawodawcę mogą być ostatecznie postrzegane jako zmierzające $\mathrm{w}$ kierunku ograniczenia ustrojowej samodzielności samorządu województwa. Współpraca zagraniczna objęta jest $\mathrm{w}$ tym przypadku szczególnym nadzorem organu niebędącego - w myśl ustawy zasadniczej oraz ustaw samorządowych - organem właściwym do sprawowania nadzoru nad działalnością jednostek samorządu terytorialnego, do tego opartym na niejasnych kryteriach.

\section{Literatura}

Bandarzewski K., Wspótpraca zagraniczna, [w:] P. Chmielnicki (red.), Komentarz do ustawy o samorządzie województwa, Warszawa 2005.

Bucholski R., Europejskie ugrupowanie wspótpracy terytorialnej (EUWT) jako międzynarodowa forma wspótpracy jednostek samorządu terytorialnego, [w:] J. Sługocki (red.), Samorząd terytorialny w Polsce i w Europie. Doświadczenia i dylematy dalszego rozwoju, Bydgoszcz 2009.

Bussmann A., Europejskie ugrupowanie wspótpracy terytorialnej (EUWT) - przełom we wspótpracy transgranicznej w Unii Europejskiej?, „Samorząd Terytorialny” 2008, nr 10.

Bussmann A., Instrumenty wspótpracy transgranicznej $w$ świetle międzynarodowego prawa publicznego (traktat z Karlsruhe) i prawa europejskiego, [w:] K. Nowacki, R. Russano (red.), Prawne problemy regionalizacji w Europie, Wrocław 2008.

Cybulska R., Komentarz do art. 76, [w:] B. Dolnicki (red.), Ustawa o samorządzie województwa. Komentarz, Warszawa 2012.

Czarnow S., Wspótpraca zagraniczna województw, „Państwo i Prawo” 2000, z. 11.

Dołzbłasz S., Raczyk A., Wspótpraca transgraniczna w Polsce po akcesji do UE, Warszawa 2010.

Iwanowski S., Sitniewski P., Znaczenie porozumień administracyjnych w nowych warunkach ustrojowych samorzadu terytorialnego, [w:] S. Dolata (red.), Prawne i finansowe aspekty funkcjonowania samorzadu terytorialnego, t. I, Prawo samorzadowe i administracyjne, Opole 2000.

Izdebski H., Samorzad terytorialny. Podstawy ustroju i działalności, Warszawa 2006.

Jankowski P., Nadzór nad samorzadem województwa, „, Przegląd Prawa Publicznego” 2010, nr 12.

Jaworska-Dębska B., Współdziałanie i „,ruch zadań” w systemie samorządu terytorialnego, [w:] M. Stahl (red.), Prawo administracyjne. Pojęcia, instytucje, zasady w teorii i orzecznictwie, Warszawa 2013.

Jóskowiak K., Wspótpraca transgraniczna i międzyregionalna Polski u progu członkostwa w Unii Europejskiej, ,, Samorząd Terytorialny” 2003, nr 5.

Kaczmarczyk K., Wybrane aspekty wspótpracy transgranicznej, „, Samorząd Terytorialny” 2001, $\mathrm{nr} 7-8$.

Kasiński M., Monizm i pluralizm władzy lokalnej. Studium prawno-polityczne, Łódź 2009.

Korczak J., Nowacki K., Współdziałanie komunalne i regionalne w obszarze przygranicznym. Euroregiony polskie, [w:] K. Nowacki, R. Russano (red.), Prawne problemy regionalizacji w Europie, Wrocław 2008.

Korniievskyi S., Role of the local government in the cross-border and interregional cooperation between Poland and Ukraine, ,, Administracja. Teoria - Dydaktyka - Praktyka” 2014, nr 2.

Kusiak R., Wspólpraca regionów i gmin o zasięgu przekraczającym granice państwowe, ,, Samorząd Terytorialny" 1996, $\mathrm{nr} 7-8$.

Kusiak-Winter R., Współpraca jednostek samorządu terytorialnego ze społecznościami lokalnymi i regionalnymi innych państw w świetle problematyki dychotomicznego podziału państwa, [w:] 
S. Wrzosek, M. Domagała, J. Izdebski, T. Stanisławski (red.), Przegląd dyscyplin badawczych pokrewnych nauce prawa i postepowania administracyjnego, Lublin 2010.

Maćkowiak J., Wspótpraca międzynarodowa województw - aspekty prawne, „Kontrola Państwowa” 2002 , nr 6.

Malinowska A., Wspólpraca zagraniczna samorządu województwa - zagadnienia wybrane, „Przegląd Prawa Publicznego" 2012, nr 7-8.

Ofiarska M., Formy publicznoprawne współdziałania jednostek samorzadu terytorialnego, Warszawa 2008.

Perkmann M., Building Governance Institutions Across European Borders, „Regional Studies” 1999, vol. 33. 7.

Sokolewicz W., Komentarz do ustawy o samorzadzie województwa, Warszawa 2000.

Soldatos P., An Explanatory Framework for the Study of Federated States and Foreign Policy Actors, [w:] H.J. Michelmann, P. Soldatos (eds.), Federalism and International Relations - The Role of Subnational Units, Oxford 1990.

Sowiński R., Ustawowa regulacja udziatu jednostek samorządu terytorialnego w międzynarodowych zrzeszeniach społeczności lokalnych, „Samorząd Terytorialny” 2002, nr 7-8.

Sowiński R., Udzial polskich samorządów w zrzeszeniach międzynarodowych, „Samorząd Terytorialny" 2002, $\mathrm{nr} 6$.

Tomaszewski K., Regiony w procesie integracji europejskiej, Kraków 2007.

Wiktorowska A., Prawne determinanty samodzielności gminy - zagadnienia administracyjnoprawne, Warszawa 2002.

Wlaźlak K., Komentarz do art. 18 ust. 2 pkt 12a, [w:] P. Chmielnicki (red.), Ustawa o samorzadzie gminnym. Komentarz, Warszawa 2013.

Woźniak M., Wspótpraca międzynarodowa jednostek samorządu terytorialnego $w$ świetle prawa polskiego i standardów międzynarodowych, „Samorząd Terytorialny” 2005, nr 4.

Zięba-Załucka H., Wspótpraca międzynarodowa samorządów, „Samorząd Terytorialny” 2008, nr $1-2$.

Zimmermann J., Prawo administracyjne, Kraków 2006.

\section{Orzecznictwo}

Rozstrzygnięcie nadzorcze Wojewody Dolnośląskiego z dnia 4 czerwca 2001 r., PN.II.0911-3/14/01, „Orzecznictwo w Sprawach Samorządowych” 2001, nr 4, poz. 127. 